\title{
"Uma terra hospitaleira de muitos imigrantes vindos do mundo todo": a emergência do discurso do multiculturalismo no Canadá
}

\section{"A hospitable land of many immigrants from all over the world": the emergence of the discourse of multiculturalism in Canada}

Diego Barbosa da Silva ${ }^{1}$

Submetido em 17 de fevereiro e aprovado em 19 de março de 2018.

Resumo: O objetivo desta pesquisa, inscrita no aparato teórico-metodológico de Michel Pêcheux e Eni Orlandi, é analisar o funcionamento do discurso do multiculturalismo no Canadá, onde teria emergido nos anos 1960. Inscrito no discurso sociológico, o discurso do multiculturalismo emerge, assim, na ilusão de que existem fronteiras entre culturas e como se a diferença não fosse constitutiva do processo de identificação dos sujeitos. Investiga-se também, o contexto de surgimento do significante multiculturalismo e os deslocamentos e silenciamentos de sentido produzidos em relação às diferenças na tensão entre franco e anglofalantes e mostra-se que para o discurso do multiculturalismo se tornar hegemônico foi preciso produzir deslocamentos no discurso de fundação do Canadá para a construção do mito de uma terra hospitaleira para imigrantes do mundo todo.

Palavras-chave: Discurso do multiculturalismo. Canadá. Análise do discurso. Interculturalismo.

\begin{abstract}
The purpose of this research, inscribed in the theoretical-methodological apparatus of Michel Pêcheux and Eni Orlandi, is to analyze the emergence of the discourse of multiculturalism in Canada, where it would have emerged in the 1960s. Inscribed in the sociological discourse, the discourse of multiculturalism thus emerges under the illusion that there are boundaries between cultures and as if the difference was not constitutive of the process of identifying the subjects. It is also investigated in the context of the emergence of the significant multiculturalism and the displacements and silencements of meaning produced in relation to the differences in the tension between Franc and Anglo speakers and it is shown that for the discourse of multiculturalism to become hegemonic it was necessary to produce displacements in the discourse of the foundation of Canada to build the myth of a hospitable land for immigrants from around the world.
\end{abstract}

Keywords : Discourse on multiculturalism. Canada. Discourse analysis. Interculturalism. 
Nos últimos anos observamos o crescimento do discurso do multiculturalismo, bem como o enfrentamento de discursos sobre a diferença, entre aqueles de ódio e aqueles a favor da diversidade. Neste artigo analisamos a emergência deste discurso no Canadá com base na análise materialista do discurso de Pêcheux e Orlandi.

Tal interesse por essa nação se justifica pela construção de uma evidência nas Ciências Sociais (DOYTCHEVA, 2005, p. 7; HEYWOOD, 2010, p. 95; RATTANSI, 2011, p. 7) ${ }^{2}$ e afirmada pelo próprio governo (CANADÁ, 2011), de que o Canadá foi o primeiro país a adotar medidas políticas em prol da diferença que, nas décadas seguintes, se espalharam pelo mundo, além de ser o único que preserva tais políticas na sua constituição ${ }^{3}$ (KYMLICKA, 2014 [2012], p.138), e a se destacar pelo mito de uma terra hospitaleira para imigrantes.

De acordo com o último censo nacional, de 2011, 20,6\% da população canadense ou 6,8 milhões de pessoas nasceram no exterior e de acordo com dados do Department of Citizenship and Immigration, o país recebe, desde 1991, anualmente cerca de 250 mil imigrantes dos cinco continentes ${ }^{4}$. Além disso, nos últimos anos, o governo canadense e os de suas províncias têm investido em propaganda na busca de novos imigrantes para trabalharem no país, um país que, como diz um dos panfletos da província de Quebec, publicado em português e em outras cinco línguas, é uma "terra hospitaleira de muitos imigrantes vindos do mundo todo" (QUEBEC, 2009)5. Nos materiais publicitários do governo, o Canadá é vendido como um país promissor, "uma nação completamente moderna, baseada no conhecimento, com uma governança, corporações, cultura e estilo de vida de nível mundial" (QUEBEC, 2009), em que

ano após ano, tem sido qualificado pelas Nações Unidas como um dos países com melhor qualidade de vida, considerando o nível e a expectativa de vida, assim como o nível educacional de sua população. Por seu desenvolvimento histórico, social e cultural, o Canadá é um país multicultural que se caracteriza por seu espírito de moderação e tolerância; é um país unido dentro de sua própria diversidade. Este caráter multicultural da sociedade canadense tem sido reconhecido oficialmente pelo governo federal, cujas políticas promovem a diversidade e favorecem a manutenção das culturas e tradições dos imigrantes e dos povos autóctones (CANADÁ. Embaixada Canadense em Brasília, 2015). 
Mesmo sendo um país cujos habitantes apresentam diferentes origens desde as colonizações francesa e inglesa, o Canadá nem sempre foi uma terra hospitaleira para pessoas das mais variadas culturas. Indo adiante, o processo de construção desse mito passa pela sua negação como país monocultural na tensão da emergência do multiculturalismo em território canadense ${ }^{6}$, como veremos a seguir.

Desde o final da Guerra dos Sete Anos (1756-1763), quando o Canadá deixou de ser colônia francesa para se tornar inglesa, os francofalantes passaram a reivindicar alguns direitos, entre eles, a igualdade de tratamento pelo Estado federal ${ }^{7}$. Em 1963, durante a Révolution Tranquille ${ }^{8}$, o primeiro ministro Lester B. Pearson, do Partido Liberal criou a Royal Commission on Bilingualism and Biculturalism/Commission royale d'enquête sur le bilinguisme et le biculturalisme $e^{9}$ que funcionou até 1969. Tal comissão deliberou:

a) That bilingual districts be created in regions of Canada where members of the minority community, either French or English, made up $10 \%$ or more of the local population; b) That parents be able to have their children attend schools in the language of their choice in regions where there is sufficient demand; c) That Ottawa become a bilingual city e d) That English and French be declared official languages of Canada (CANADÁ, 1969) ${ }^{10}$.

A partir dessa data pode-se afirmar que o Canadá deixou oficialmente de ser um Estado monolíngue para se tonar um Estado bilíngue, produzindo uma ruptura na ideologia nacionalista de uma língua = uma nação, bem como nas formas de existência, experiência dos sujeitos. Afinal, daquele momento em diante, o Estado canadense e o seu espaço de poder iriam significar-se a partir de duas matrizes de sentido, com memórias de colonização distintas sobre a língua, pois

não há possibilidade de se ter a língua que não esteja já afetada desde sempre pelo político. Uma língua é um corpo simbólicopolítico que faz parte das relações entre sujeitos na sua vida social e histórica. Assim, quando pensamos em políticas de línguas, já pensamos de imediato nas formas sociais sendo significadas por e para sujeitos históricos e simbólicos, em suas formas de existência, de experiência, no espaço político de seus sentidos (ORLANDI, 2007, p. 8). 
No entanto, o Canadá já era um país composto por outros grupos culturais, além de aborígenes, migrantes advindos de outros países europeus e asiáticos, sobretudo chineses, japoneses, alemães e ucranianos, que durante os processos da Royal Commission reivindicaram também maiores espaços e direitos (CONRAD, 2012, p. 247).

Foi, assim, durante o período de funcionamento da comissão que, Charles Hobart, professor de sociologia da Universidade de Alberta, e Paul Yuzyk ${ }^{11}$, professor de estudos eslavos e de história da Universidade de Manitoba, usaram o termo multicultural pela primeira vez no Canadá, nos anos $1960^{12}$. O primeiro, durante sua apresentação na 6 th Conference of the Canadian Council of Christians and Jews, realizada em Winnipeg, em 1964, quando falou de uma sociedade multicultural, aplicando o termo ao Canadá. E o segundo, em 3 de março de 1964, quando designou o Canadá como uma nação multicultural, em seu primeiro discurso como senador pelo Partido Conservador representando a província de Manitoba (RICHTER, 2011, p. 36).

Como podemos observar, então, o significante multicultural foi utilizado pela primeira vez inscrito no discurso sociológico. Segundo Orlandi (1989, p. 42), “toda denominação acarreta em silêncio que o fato mesmo de nomear produz. Toda fala instala espaços de silêncios e o ato de nomear recorta esses espaços definindo-os". Assim, silenciando outras possibilidades de significar, o significante multicultural surge ancorado nas evidências sociológicas de que é possível determinar os limites entre duas ou mais culturas, ou seja, de que existem diferenças grandes o suficiente para se determinar que uma cultura é diferente de outra, que um grupo de indivíduos pertence a essa cultura e não àquela outra $^{13}$. Isso ocorre como se tais recortes do real não fossem também imaginários, mesmo que advindos da Sociologia, que se julga neutra, como qualquer ciência e como se fosse possível apreender quem fosse indiano ou chinês, ou como se não fosse possível ser chinês e indiano, delimitando fronteiras entre culturas, ignorando inclusive os variados processos de identificação e de inscrição do sujeito. E mais, como se fosse óbvio que, se um espaço tivesse mais que duas culturas, ele poderia e deveria ser designado como multicultural ${ }^{14}$.

Cabe aqui expor que para Pêcheux (2009 [1975], p. 198), “os indivíduos são 'interpelados' em sujeitos falantes (em sujeitos de seu discurso) por formações discursivas que representam 'na linguagem' as formações ideológicas que lhes são correspondentes". 
Entretanto, “a interpelação do indivíduo em sujeito de seu discurso se realiza pela identificação (do sujeito) com a formação discursiva que o domina". Nesse processo de identificação, contraidentificação e desidentificação do sujeito em distintas formações discursivas é possível que o sujeito se identifique com mais de uma formação discursiva e seja interpelado por processos discursivos distintos. Tomamos assim, o pertencimento a uma cultura como um processo de identificação do sujeito a um discurso dessa cultura ou dessa nacionalidade. Desse modo, é possível que um mesmo sujeito se identifique como indiano e chinês ao mesmo tempo, independentemente de onde tenha nascida ou de onde venham os seus antepassados. Afinal, como nos mostra Pêcheux (2010 [1983]) as formações discursivas não são homogêneas. Justamente para prosseguirem no seu processo de dissimulação são heterogêneas e estão constantemente em movimento.

Cultura, assim, na transparência do discurso sociológico, é tomada apenas como uma origem única, na maioria das vezes relacionadas a um Estado (a cultura canadense, como uma unidade, não cabendo culturas canadenses, nem culturas inuítes), e como algo estático, que pode ser capturado no momento da denominação, em que se pode afirmar a cultura é assim, e a cultura não é assim, não cabendo o movimento e a transformação. Tais evidências mascaram as condições de produção em que se deu a constituição material dos sentidos no discurso sociológico sobre cultura. Dessa maneira, só é possível dizer multicultural em referência a muitas culturas sob tais evidências sociológicas ${ }^{15}$.

Para Pêcheux (2009 [1975]), uma vez que os sujeitos são sempre-já sujeitos, interpelados pela ideologia, sua existência e relação com o real só é possível por meio de formas-sujeito próprias de cada formação ideológica. Já a tomada do dizer só é possível por meio de posições-sujeito, que se constituem na relação de identificação entre sujeito enunciador e a forma-sujeito. Em cada formação discursiva podem se inscrever muitas posições, inclusive antagônicas, o que reforçaria o processo de dissimulação de uma mesma formação discursiva (cf. Grigoletto, 2004).

Refletindo, desse modo, de outra posição, do analista do discurso, quando se pensa o caráter multilíngue e por que não dizermos também multicultural, concordamos com Orlandi (2012, p. 6) que: 
Não há país que não seja multilíngue. Dito de outro modo: não há país monolíngue. Não há Estado que, embora em sua institucionalidade apresente sua ou suas línguas oficiais, nacionais, não se faça no contato com múltiplas línguas. E a língua não é una, não é uma, não é pura. É feita de falhas, de mudanças, de contatos variados. As línguas mudam, entram em contato entre si, desaparecem, se criam. Estão sempre incompletas, em movimento, assim como as identidades são um movimento na história. Não há Nação que não produza uma riqueza imensa na relação de sua(s) língua(s) e sua(s) cultura(s). Relação complexa, portanto, que não existe em linha reta, não é exata e demanda que se pense a história, a sociedade, e a política.

Sob essa posição, o multilinguismo e o multiculturalismo se ancoram em redes de sentidos que não aquelas de unidade, pureza e uniformidade, construídas na relação com o Estado, mas em outras em que a diferença é constitutiva, construída na relação histórica entre sujeitos, entre línguas e culturas. Contudo, são sob os efeitos de sentido de cultura no discurso sociológico e não naquele do analista do discurso que, seguindo as recomendações posteriores da Royal Commission ${ }^{16}$, Pierre Elliott Trudeau, advogado, filho de mãe anglofalante e pai francofalante e primeiro-ministro de 1968 a 1979 e de 1980 a 1984, pelo Partido Liberal, foi ao Parlamento, no dia 8 de outubro de 1971 e apresentou uma mudança de política, do biculturalismo para o multiculturalismo.

Para Trudeau (1971):

The distinction between language and culture has never been clearly defined. The very name of the royal commission whose recommendations we now seek to implement tends to indicate that bilingualism and biculturalism are indivisible. But, biculturalism does not properly describe our society; multiculturalism is more accurate. The Official Languages Act designated two languages, English and French, as the official languages of Canada for the purposes of all the institutions of the Parliament and government of Canada; no reference was made to cultures, and this act does not impinge urn the role of all languages as instruments of the various Canadian cultures ${ }^{17}$.

Iniciando o modelo que foi chamado pelo próprio Trudeau (1971) de uma política de multiculturalismo dentro de uma estrutura bilingue, o reconhecimento do Canadá como um país de várias culturas, ou seja, multicultural, se deu a partir de dois deslocamentos, o primeiro de monocultural para bicultural, o segundo, de bicultural para 
o multicultural, embora o país se mantivesse oficialmente apenas bilíngue. A emergência do discurso do multiculturalismo no Canadá permitiu que se passasse de uma nação, duas culturas, para uma nação, várias culturas. Já no que tange à língua, o que temos é uma nação, duas línguas e não várias línguas. Em outras palavras, admitem-se várias culturas, mas não várias línguas. Os sujeitos no Canadá poderiam ter, então, outras culturas, mas jamais outras línguas.

Se para Orlandi (2007 [1999], p. 22), a língua é "condição de possibilidade do discurso", uma vez implementado o multiculturalismo, mas não o multilinguismo, silenciaram-se, assim, várias línguas e os sentidos que elas traziam em sua materialidade e memória. Manteve-se o controle das línguas e dos sentidos por parte do Estado. Todo dizer entre as distintas culturas com o próprio Estado e entre elas se daria sob o controle desse mesmo Estado, por meio das duas línguas oficiais, pois para descrever e contar outra história que não a oficial, seria "necessário inscrevê-la num universo simbólico que não é outro senão o de práticas significativas já previamente constituídas" (MARIANI, 2004, p. 24) nas/pelas línguas oficiais ${ }^{18}$. Não seria possível, assim, no Canadá a permanência no país de outra cultura que não se expressasse ou significasse o mundo por meio do inglês ou do francês, mesmo que outras línguas fossem utilizadas na esfera privada. O efeito que se produz para o diferente, analisando os documentos, é o de que o país deixou de ser uma nação "bicultural e bilíngue" para se tornar legalmente uma nação "multicultural, porém bilíngue", em inglês e francês 19 .

Essa contradição do "multicultural, porém bilíngue", se mostra quando observamos os seus efeitos na província canadense francofalante do Quebec. Após a implementação do multiculturalismo, o Quebec tomou uma série de medidas de proteção da língua francesa, tendo como a principal, a Charte de la langue française, também chamada de loi 101, de 1977, durante o governo de René Lévesque, do Parti québécois, quando o estado de bilíngue passou a ser oficialmente monolíngue. Para Gagnon e Iacovine (2003, p. 456), após o multiculturalismo, o Quebec buscava uma segurança linguística por meio da preservação de sua língua, o francês, em um estado com taxa de natalidade em queda, em um país cujo foco na variedade, na multiplicidade de culturas favoreceria a integração de imigrantes por meio da língua 
inglesa, e em um subcontinente (América do Norte) cuja maioria da população é falante materno de inglês.

Uma vez monolíngue, não caberia manter a denominação biculturalismo, nem o multiculturalismo e a província passou a denominar suas medidas políticas em prol da diferença como interculturalismo acentuando que a diferença estaria na cultura e não na língua. Isso ocorreu em 1981, dez anos após o discurso de Trudeau no Parlamento e durante a reforma constitucional promovida pelo primeiro-ministro sem a concordância da província de Quebec, que buscava maior autonomia ${ }^{20}$ (MAHROUSE, 2010, p. 86).

Da posição francofalante, o reconhecimento do multiculturalismo apagaria o biculturalismo e diminuiria a importância do Quebec como nação, condenando os canadenses de origem francesa a ser mais uma cultura entre as tantas outras do Canadá (BOUCHARD, 2011, p. 462) ${ }^{21}$. O multiculturalismo, portanto, os colocava em uma posição de inferioridade, no espaço político canadense. Essa medida, de acordo com Laczko (1995) desencadeou reações políticas por parte do governo de Quebec, entre elas a formulação e a implantação da política do interculturalismo. Já Taylor (2012), na posição de sociólogo, afirma que, criado no nacionalismo quebequense para o governo de Quebec, o interculturalismo favoreceria a integração e não uma integração qualquer, ao contrário do multiculturalismo, que apenas se focaria na diversidade, na multiplicidade 22 .

Se observarmos o significado do prefixo inter-, no dicionário de língua inglesa Oxford (1989), temos "between, among, amid, in beteween, in the midst" ${ }^{23}$ e no dicionário de língua francesa Robert (1989), “exprimant l'espacement, la répartition (dans l'espace et dans le temps), soit une relation, un lien de réciprocité" 24.

Nota-se que tal deslocamento do prefixo viria a produzir um efeito de reciprocidade no convívio entre as variadas culturas, dando ênfase à relação entre elas em oposição àquela dada em relação à quantidade de culturas no país que até então vinha significando o discurso sobre a cultura nacional no/do Canadá. O interculturalismo produziria, assim, um efeito de hospitalidade às outras culturas por meio de uma integração intercultural que deveria ocorrer, mas que só seria possível por meio da língua francesa. Como vimos, a questão linguística novamente não seria deslocada ${ }^{25}$. Há que se observar que o que está em jogo são duas línguas e a relação entre elas - inglês e francês - o que impossibilita 
de dizer, por sua vez, seja no Quebec, seja no Canadá, interlíngue ou interlinguismo. Na posição dos francofalantes, tanto o Canadá quanto o Quebec deveriam ser interculturais; porém o primeiro deveria ser bilíngue e o segundo, monolíngue. Além disso, dessa mesma posição não se poderia dizer multiculturalismo porque aí os francofalantes seriam um dentre vários.

Uma vez compreendidos os deslocamentos e a tensão entre posições francofalante e anglofalante no Canadá, observamos que o primeiro termo para designar a variedade cultural canadense foi o adjetivo multicultural, de "uma nação multicultural", "uma sociedade multicultural" nos anos 1960. Porém, no pronunciamento de Trudeau lemos "biculturalism does not properly describe our society; multiculturalism is more accurate"26 (grifos nossos), em que temos o substantivo multiculturalismo. Para Mariani (1998, p. 118), a denominação, enquanto um modo de construção discursiva dos "referentes", tem como característica a capacidade de condensar em um substantivo, ou em um conjunto parafrástico de sintagmas nominais e expressões, "os pontos de estabilização de processos" resultantes das relações de força entre formações discursivas em concorrência num mesmo campo (...) O processo de denominação não está na ordem da língua ou das coisas, mas organiza-se na ordem do discurso, o qual relembrando mais uma vez, consiste na relação entre o linguístico e o histórico-social, ou entre linguagem e exterioridade.

Desse modo, prefixos e sufixos não estão de fora do processo discursivo, pelo contrário, nomear utilizando um sufixo é dar a algo uma existência histórica (GUIMARÃES, 2003, p. 54). Segundo Azeredo (2008, p. 456),

a possibilidade de conferir uma nova classe à palavra derivada faz
da sufixação um processo de extraordinária versatilidade na língua.
Enquanto a prefixação contribui ordinariamente para a ampliação do
léxico, a sufixação, além dessa função, tem um papel importante na
construção sintática dos sintagmas, das orações e até mesmo do texto.

Observando, no entanto, o discurso do multiculturalismo, notamos que a formação de um substantivo que denominasse a diferença no Canadá, deu-se pelo sufixo -ism/-isme (ismo) e não pelo -ity/-té (-[i]dade). Vejamos o que dizem dois dicionários britânicos de língua inglesa e dois de língua francesa, um canadense e outro francês, sobre esses dois sufixos. 


\begin{tabular}{|c|c|c|}
\hline Dicionário & -ism / -isme & -ity / -(i)té \\
\hline Oxford (1989) & $\begin{array}{l}\text { 1. Forming a simple noun of action, nam- } \\
\text { ing the process, or the completed action, or } \\
\text { its result (rarely concrete) }(. . .) ; 2 \text {. Forming } \\
\text { the name of system of theory or practice, } \\
\text { religious, ecclesiastical, philosophical, } \\
\text { political, social, etc., sometimes founded } \\
\text { on the name of its subject or object, some- } \\
\text { times on that of its founder }(\ldots) \text { b. More } \\
\text { of the nature of class-names or descrip- } \\
\text { tive terms, for doctrines or principles, are } \\
\text { agnostism }(\ldots) \text { feminism }(. . .) ; 3 \text {. Forming a } \\
\text { term denoting a peculiarity of characteris- } \\
\text { tic, esp. of language }{ }^{27} \text {. }\end{array}$ & Não existe entrada. \\
\hline Longman (1987) & $\begin{array}{l}\text { Suffix [in nouns] } 1 \text { a political belief or reli- } \\
\text { gion based on a particular principle or the } \\
\text { teachings of a particular person: socialism/ } \\
\text { Buddhism } 2 \text { the action or process of doing } \\
\text { something (...) } 3 \text { an action or remark that } \\
\text { has a particular quality (...) } 4 \text { the state of } \\
\text { being like something or someone, or having } \\
\text { a particular quality (...) } 5 \text { illness caused by } \\
\text { too much of something: alcoholism } 6 \text { the } \\
\text { practise of treating people unfairly because } \\
\text { of something: sexism (...) racism (...). }{ }^{28}\end{array}$ & $\begin{array}{l}\text { Suffix [in nouns] the state of } \\
\text { having a particular quality, } \\
\text { or something that has that } \\
\text { quality: with great regularity } \\
\text { (= regularly) / such stupidities } \\
\text { (=stupid actions or remarks) }\end{array}$ \\
\hline
\end{tabular}




\begin{tabular}{|c|c|c|}
\hline Robert (1989) & $\begin{array}{l}\text { Suffixe, du grec -ismos (qui eut une } \\
\text { extension parallèle à celle du suffixe } \\
\text { verbal -idzein } \rightarrow \text {-iser, et dans lequel on } \\
\text { reconnaît l'elément nasal -mo- à l'origine } \\
\text { de -me dan enthousiasme, marasme, } \\
\text { miasme, spasme...), passé en français par } \\
\text { l'intermédiaire du latin de basse époque } \\
\text {-ismus, et qui sert à la formation de } \\
\text { substantifs dérivés masculins, désignant une } \\
\text { profession, une opinion (ex.: socialisme, } \\
\text { journalisme) l'appartenance à un groupe } \\
\text { ou à un système (ex.: structuralisme), } \\
\text { etc. => -iste. Le suffixe -isme est très } \\
\text { productif; ajouté à un nom ou un adjectif, } \\
\text { il forme des termes politiques et sociaux, } \\
\text { avec la valeur axiologique de «système } \\
\text { d'opinions» ou de «attitude, tendance»; } \\
\text { des termes de philosophie, de religion ou } \\
\text { de science («doctrine» ou «croyances»); } \\
\text { des termes littéraires et artistiques } \\
\text { («écoles, tendances»). Il a toujours la } \\
\text { valeur de «attitude positive par rapport } \\
\text { à (une croyance, etc., représentée par la } \\
\text { base)»- Une deuxième valeur du suffixe } \\
\text { est celle d' «attitude et activité» conforme } \\
\text { à la tendance ou au modèle qu'exprime } \\
\text { la base (bovarysme, constructivisme, } \\
\text { etc.) ou favorable à une personne, un } \\
\text { groupe humain, etc. (américanisme; } \rightarrow \\
\text { Pro-). - À côte de as valeur de «activité } \\
\text { professionnelle» (journalisme), -ismeacelle } \\
\text { de «caractère ou état particulier, maladie» } \\
\text { (mongolisme, virilisme) ou «activité } \\
\text { quelconque» (canoéisme, etc.). Outre les } \\
\text { bases nominales et adjectives du lexique, } \\
\text {-isme se construit avec des noms propres, } \\
\text { notamment en politique (=> Gaullisme; } \\
\rightarrow \text { Pompidolisme; giscardisme; barrisme; } \\
\text { mitterrandisme...), des verbes (dirigisme), } \\
\text { des syntagmes (aquoibonisme) } \\
\text { 30. }\end{array}$ & $\begin{array}{l}\text { Suffixe (du lat. -itas) servant à } \\
\text { former des substantifs, sur une } \\
\text { base adjective ou, exception- } \\
\text { nellement, nominale. Adj. en } \\
\text {-able et -ible = -abilité, -ibilité } \\
\text { (ex.: manœuvrabilité, réversi- } \\
\text { bilité); adj. en -aire = -arité } \\
\text { (ex.: primarité); adj. en -al } \\
\text { et -el = -alité (ex.: atonalité, } \\
\text { fonctionnalité, fiscalité); } \\
\text { adj. en -eux = -osité (ex.: } \\
\text { adiposité, schistosité); adj. } \\
\text { en -if = -ivité (ex.: sportivité, } \\
\text { positivité); adj. en -ique (ex.: } \\
\text { historicité). Autres adj. (ex.: } \\
\text { factice = facticité). Noms } \\
\text { (ex.: alumine = aluminité) }{ }^{31} \text {. }\end{array}$ \\
\hline Larousse (1989) & Não existe entrada & Não existe entrada \\
\hline
\end{tabular}

Como sabemos, as línguas de origem ou influência latina e grega, como as duas línguas oficiais do Canadá, permitem a formação de substantivos a partir de verbos e adjetivos por meio dos sufixos -ism/-isme [-ismo] e -ity/-(i)té [-(i)dade]. O primeiro, 
além de alterar a classe da palavra base, produz um outro efeito de sentido, de doutrina, de crença, de teoria, já o último, embora mudando a categoria da palavra, manteria o sentido de qualificar, como pode ser observado nos verbetes dos dicionários. Levando em consideração, a memória lexicográfica e o estabelecimento pelos dicionários do "que não deve ser esquecido em matéria das palavras e de discursos ligados a uma língua" (HORTA NUNES, 2013), seria possível a formação de um substantivo para representar a situação cultural do Canadá por meio do sufixo -ismo ou por meio do -(i)dade.

Contudo, o deslocamento para a formação desse substantivo a ser utilizado pelo governo, ocorre com o sufixo -ism [-isme, em francês] e não com o sufixo -ity [-(i)té, em francês], que poderia formar a palavra multiculturality/multiculturalité, criando-se a ilusão de que apenas a primeira forma de dizer fosse possível.

Partindo da articulação teórica de Althusser (1985 [1970]) de que os indivíduos sejam interpelados livremente em sujeitos para livremente se assujeitarem à submissão, Pêcheux afirma que isso só é possível a partir de dois esquecimentos da ordem do inconsciente, afinal "sendo "sempre-já" sujeito, ele "sempre-já" se esqueceu das determinações que o constituem como tal” (PÊCHEUX, 2009 [1975], p. 158).

Concordamos em chamar esquecimento no 2 ao "esquecimento" pelo qual todo sujeito-falante "seleciona" no interior da formação discursiva que o domina, isto é, no sistema de enunciados, formas e sequências que nela se encontram em relação de paráfrase - um enunciado, forma ou sequência, e não um outro, que, no entanto, está no campo daquilo que poderia reformá-lo na formação discursiva considerada. Por outro lado, apelamos para a noção de "sistema inconsciente" para caracterizar um outro "esquecimento", o esquecimento $n^{\circ} 1$, que dá conta do fato de que o sujeito-falante não pode, por definição, se encontrar no exterior da formação discursiva que o domina. Nesse sentido, o esquecimento $n^{\circ} 1$ remetia, por uma analogia com o recalque inconsciente, a esse exterior, na medida em que - como vimos - esse exterior determina a formação discursiva em questão" (PÊCHEUX, 2009 [1975], p. 161-162).

$\mathrm{O}$ esquecimento $\mathrm{n}^{\circ} 1$ é aquele em que o sujeito-falante esquece que não é o centro do dizer, que os sentidos não emanam dele; já o esquecimento $\mathrm{n}^{\circ} 2$ é aquele em que o sujeitofalante esquece que existem outras maneiras de se formular o que foi dito. 
Quando se diz multiculturalismo ou interculturalismo, não se diz multiculturalidade ou interculturalidade ou diversidade cultural. Foi preciso esquecer que o multiculturalismo não seria a única maneira de designar a política cultural do Canadá ou mesmo as medidas políticas do país em prol da diferença, e que também seriam possíveis os termos multiculturalidade e interculturalidade.

Tal esquecimento produziu apagamentos; com o significante multiculturalismo, apagou-se, portanto, a possibilidade de dar existência a esse caráter multicultural, por meio de outro substantivo, multiculturalidade ${ }^{32}$. Silenciou-se, assim, a possibilidade de se afirmar, nas leis, o Canadá como um Estado multicultural, apagou-se no fio discursivo essa característica do país para a produção de outra ilusão de evidência, relacionada a um conjunto de ideias, que encontra ecos em outros -ismos ${ }^{50}$ como o liberalismo, o capitalismo, o comunismo e o feminismo. Foi desse modo, ancorando-se nesses outros ismos que foi construída a memória sobre a situação da diversidade no Canadá e sobre as políticas para essa mesma diversidade. Tal ancoragem torna as medidas políticas relativas a minorias culturais mais suscetíveis às turbulências políticas, e também às críticas, fragilizando-as. Afinal, como afirma Karmis (2003, p. 85), não há discordância entre os estudiosos do tema sobre o fato de o Canadá ser um país multicultural, mas sim como se opera e se normatiza tal característica. O que estamos tentando dizer é que dificilmente encontramos dizeres depreciativos utilizando os significantes diversidade cultural ou multiculturalidade. Pelo contrário, como já dissemos, criticar tais dizeres desde a hegemonia da Formação Discursiva dos Direitos Humanos, após o Holocausto, é abominável e por isso da ordem do indizível ${ }^{33}$. Por outro lado, encontramos enunciados como "o multiculturalismo fracassou" (EURONEWS, 2010; SAPO, 2011; PÚBLICO, 2011) $)^{34}$ ou "aquela palavra que começa com m" (KYMLICKA, (2014 [2012]), para não dizer multiculturalismo, o que demonstra certa interdição.

Ademais, se observarmos documentos internacionais sobre a temática tais como as resoluções Direitos Humanos e Diversidade Cultural, aprovadas constantemente na Assembleia das Nações Unidas, desde 2000, e a Declaração Universal sobre a Diversidade Cultural (2001), a Convenção sobre a Promoção e Proteção da Diversidade das Expressões Culturais (2005) e o relatório Investir na diversidade cultural e no 
diálogo intercultural (2009), no âmbito da Unesco, notaremos a utilização do significante diversidade cultural, inclusive na versões em inglês, em detrimento do significante multiculturalismo. Este só comparece, no último documento citado, quando se refere especificamente às políticas do multiculturalismo iniciadas no Canadá nos anos $1970^{35}$.

Mesmo interditando sentidos sobre a possibilidade da diversidade, a emergência do discurso do multiculturalismo se assenta em uma memória de origem do país, que se pode ler na formulação do Canadá como terra hospitaleira. Esse mito se materializa no enunciado uma terra hospitaleira de muitos imigrantes vindos do mundo todo. A construção desse mito se torna possível em um país cuja origem se significa como de forma harmoniosa no contato de várias culturas. Foi preciso, assim, apagar os conflitos gerados pela colonização. Se observarmos as sequências discursivas ${ }^{36}$, a seguir, retiradas dos Annual Report on the Operation of the Canadian Multiculturalism ${ }^{37}$ de 2008 a 2014, disponíveis na internet; da publicação Discover Canada: The Rights and Responsibilities of Citizenship, organizada pelo Department of Citizenship and Immigration, o Ministério de Cidadania e Imigração com a finalidade de serem utilizadas como material de estudo para o teste de cidadania; além da página na internet da Embaixada do Canadá em Brasília, veremos como o passado canadense foi (res)significado, com grifos nossos:

SD1.1: To understand what it means to be Canadian, it is important to know about our three founding peoples - Aboriginal, French and British (Discover Canada, 2012, p. 10) ${ }^{38}$.

SD1.2: Canada, from the very beginning, has been a diverse society with a history of accommodating newcomers and its citizens. Diversity in Canada was built on three main pillars: the Aboriginal, French and British peoples. Over time, this diversity has been complemented by millions of newcomers to Canada with various ethnic and religious backgrounds (Relatório 2010/2011, p. 10) ${ }^{39}$.

SD1.3: Canadian society rests upon a solid foundation, one built by the three founding nations, Aboriginal, French and British peoples, with strong institutions, a vibrant national culture and identity, and shared values (Relatório 2011/2012, p. 7) ${ }^{40}$.

SD1.4: The arrival of European traders, missionaries, soldiers and colonists changed the native way of life forever. Large numbers of Aboriginals died of European diseases to which they lacked immunity. However, Aboriginals and Europeans formed strong 
economic, religious and military bonds in the first 200 years of coexistence which laid the foundations of Canada (Discover Canada, 2012, p. 14) $)^{41}$.

SD1.5: A base de um Canadá multicultural remonta ao princípio da sua história. A sociedade aborígene era multicultural e multilingual. Os primeiros exploradores franceses e ingleses que chegaram ao Canadá nos séculos XVI e XVII integraram-se com as Primeiras Nações a fim de construir uma herança canadense única (Embaixada do Canadá em Brasília, 2015).

Nessas sequências discursivas (SD), podemos observar que a origem do Canadá vai ser dita como ocorrendo no encontro de três povos ${ }^{42}$ - aborígene, francês e britânico - que fundam o país de forma harmoniosa e sem conflito numa tradição para acomodar (SD1.2) e compartilhar valores (SD1.3), a fim de construir uma herança única (SD1.5). Nelas, inclusive a sociedade aborígene, no singular, já seria multicultural e multilingual (SD1.5), ou seja, acostumada e aberta ao contato com outras culturas e línguas.

Mesmo quando se afirma que um grande número de aborígenes morreram de doenças europeias (SD1.4), aparentemente denunciando que houve conflito durante a colonização, há em seguida a adversativa no entanto, aborígenes e europeus formaram fortes laços econômicos, religiosos e militares nos primeiros 200 anos de convivência, que são as bases do Canadá, que retoma a memória outra - prevalecendo-a - de que a origem do país ocorreu de forma harmoniosa. Nessas sequências, observamos o funcionamento de um enunciado, o do encontro de povos para a origem do Canadá, que diremos ser um enunciado fundador. Segundo Orlandi (2003 [1993], p. 12), enunciados fundadores são

aqueles que vão inventando um passado inequívoco e empurrando um futuro pela frente e que nos dão a sensação de estarmos dentro de uma história de um mundo conhecido (...). São enunciados que ecoam e reverberam efeitos de nossa história em nosso dia-a-dia, em nossa reconstrução cotidiana de nossos laços sociais, em nossa identidade histórica.

Para o funcionamento desses enunciados, "o sentido anterior é desautorizado. Instala-se outra 'tradição' de sentidos que produz os outros sentidos nesse lugar. Instalase uma nova 'filiação'. Esse dizer irrompe no processo significativo de tal modo que pelo seu próprio surgir produz sua memória" (ORLANDI, 2003 [1993], p. 13). São 
desautorizados, assim, outros sentidos, outras memórias, outras discursividades, entre elas duas antagônicas, a do descobrimento e a da invasão do Canadá ${ }^{43}$.

A primeira, a do descobrimento, é aquela em que se afirma que o Canadá, como outros países do continente americano, foi descoberto e povoado por europeus, e que no território havia animais, (maus) selvagens que deveriam ser exterminados ou bons selvagens que deveriam ser civilizados e cristianizados ${ }^{44}$. Nessa discursividade, hegemônica na historiografia sobre o Canadá até a emergência do discurso do multiculturalismo, o Canadá seria fundado apenas pelos dois povos europeus, já que os povos indígenas seriam aqueles conquistados e dominados. Isso pode ser observado também nas obras de Morton (1989 [1983], p. 16), sobre a história canadense, quando afirma que apenas duas são as nações fundadoras do Canadá: inglesa e francesa, e de McNaught (1988 [1969], p. 19-20) ao considerar os povos que habitavam aquele território antes dos europeus como mera descrição geográfica.

Já a segunda discursividade desautorizada, a da invasão, é aquela em que o Canadá foi invadido por franceses e britânicos, que exterminaram as populações indígenas, que já ocupavam as terras desde quando o Criador os colocou lá ${ }^{45}$. É o discurso da Assembly of First Nations/Assemblée des Premières Nations ${ }^{46}$, organização que reúne a maioria dos povos autóctones do Canadá (AFN, 1985). Nela, como muitos, senão todos os povos indígenas conquistados e exterminados na América, os indígenas do Canadá resistiram à dominação, mesmo que em silêncio "reorganizando as suas práticas significativas" (MARIANI, 2004, p. 24). Essas duas discursividades não comparecem nos textos por nós analisados.

Nos dizeres sobre a origem do Canadá, - recortados nos relatórios do governo sobre o multiculturalismo - há, assim, um apagamento do processo de colonização na América, como se os três povos tivessem decidido se unir e fundar uma nova nação por livre e espontânea vontade, não havendo espaço para o discurso do descobrimento e tampouco para o discurso da invasão ${ }^{47}$, anteriormente dominantes. Contudo, ainda que o discurso do descobrimento seja desautorizado pelo discurso do encontro, mantém-se a sua inscrição na mesma memória do colonialismo, pois como comenta Mariani (2004, p. 23-24) mantém-se a posição do colonizador: 
Se considerarmos o período das descobertas do novo mundo, observa-se que o discurso da História proveniente do colonizador, enraizado na ideologia do eurocentrismo, justifica e valoriza suas próprias ações visando ao povoamento e à defesa de uma terra conquistada, ao mesmo tempo em que silencia sobre as lutas pela imposição e/ou preservação das identidades.

Mantém-se, assim, a valorização da ação do colonizador que promoveu o encontro com o colonizado, silenciando as formas de resistência a esse processo. Silencia-se o descobrimento e a invasão para manter-se a dissimulação sobre a própria colonização. Entretanto, como "não há ritual sem falhas" (PÊCHEUX, 2009 [1975], p. 277), o processo de instalação de um enunciado fundador "aproveita fragmentos do ritual já instalado - da ideologia já significante - apoiando-se em "retalhos" dele para instalar o novo" (ORLANDI, 2003 [1993], p. 13). O enunciado fundador do encontro dos três povos e nações fundadoras do Canadá, desse modo, só é possível se considerarmos a préexistência de uma sociedade, uma nação, um Estado aborígene únicos, no mesmo sentido daquele já existente para franceses e britânicos, do descobrimento e da invasão.

Uma vez dito que o multiculturalismo se assenta nas discursividades sobre a origem do Canadá como uma terra hospitaleira, cabe agora acrescentar que isto não se dá sem deslocamento. A emergência do discurso do multiculturalismo promoveu a necessidade de ressignificar a origem da nação canadense, reservando para os povos aborígenes também o lugar social ${ }^{48}$ de fundação, como diz Karmis (2003, p. 88) foi preciso modificar "a história nacional tal como foi ensinada há dois séculos". Assim, criou-se uma "tradição de sentidos projetando-se para frente e para trás, trazendo o novo para o efeito do permanente (...). Produz, desse modo, o efeito do familiar, do evidente, do que só pode ser assim" (ORLANDI, 2003 [1993], p. 13-14).

Somente a partir dessa outra memória, de um outro passado em que o Canadá foi fundado pelo encontro harmonioso de três povos distintos, foi possível construir o mito de uma terra hospitaleira para os imigrantes do mundo todo em que o discurso do multiculturalismo se tornou hegemônico. 


\section{Conclusão}

Neste artigo, levantamos alguns pontos em torno da emergência do discurso do multiculturalismo no Canadá. Vimos que ele emerge no discurso sociológico na ilusão da cultura como algo estático e homogêneo com fronteiras bem delimitadas, mas sem produzir deslocamentos no discurso político canadense sobre as línguas oficiais. Além disso, vimos que tal discurso do multiculturalismo emerge no conflito entre franco e anglofalantes nos anos 1960 e permanece em tensão entre as duas comunidades como pode ser observado na disputa entre os significantes multiculturalismo e interculturalismo. Mostramos também que em tal discurso o sentido de muitas culturas se estabiliza por meio de um substantivo com sufixo -ismo e não por meio de um adjetivo ou de um substantivo que indique uma qualidade como multiculturalidade ou mesmo um sintagma nominal como diversidade cultural. Com isso, tal discurso encontra ecos em outros ismos como socialismo e liberalismo, passando a significar no discurso sociológico em que se inscreve como uma ideologia e por isso passa a ser alvo de críticas. Além disso, observamos que o discurso do multiculturalismo movimenta enunciados fundadores que desautorizam sentidos anteriores produzindo uma outra memória sobre o surgimento do Canadá, mas que contudo não apagam a memória do colonialismo.

Por fim, cabe dizer o que esperamos com esta análise foi levantar questionamentos e produzir reflexões sobre o funcionamento e os efeitos de obviedade produzidos no/pelo discurso do multiculturalismo ao significar, na ilusão da inclusão, as diferenças.

\section{Referências}

AFN (Assembly of First Nations/Assemblée des Premières Nations), 2015. Disponível em: <http://www.afn.ca/index.php/en>. Acesso em: 10 ago. 2015.

. Charter of the Assembly of First Nations, de 1985, com emendas de 2003. Disponível em: <http://www.afn.ca/en/about-afn/charter-of-the-assembly-of-firstnations $>$. Acesso em: 10 ago. 2015.

AGUIRRE, Pablo Armando González Ulloa. El multiculturalismo em Canadá: la redefinición de las políticas de la inclusión y sus teóricos. In: Norteamérica, año 9, n. 1, jan./jun. 2014. Disponível em: <http://www.sciencedirect.com/science/article/pii/ S187035501470117X>. Acesso em: 15 set. 2015. 
ALTHUSSER, Louis. Aparelhos ideológicos de Estado. Rio de Janeiro: Graal, 1985 [1970].

AZEREDO, José Carlos de. Gramática Houaiss da Língua Portuguesa. São Paulo: Publifolha, 2008.

BALTHAZAR, Louis. Quebec and the ideal of federalism. In: Annals of the American Academy of Political and Social Science, v. 538, 1995. Disponível em: $<$ http://ann. sagepub.com/content/538/1/40>. Acesso em: 10 ago. 2015.

BARBOSA DA SILVA, Diego. Multiculturalismo no Canadá: uma análise do discurso do primeiro-ministro Pierre Trudeau. In: Anais do Seminário Interno de Pesquisas do Laboratório Arquivos do Sujeito. Universidade Federal Fluminense: Niterói, 2013.

. Dizer na cultura para dizer da diferença: o discurso da diversidade no discurso da política no Brasil. Tese (Doutorado em Estudos de Linguagem) - Instituto de Letras, Universidade Federal Fluminense. Niterói, 2016.

BOBBIO, Norberto. A Era dos Direitos. Rio de Janeiro: Campus, 2004.

BOUCHARD, Gérard. What is interculturalism? In: McGill Law Journal, v. 56, n. 2, 2011. Disponível em: <http://www.symposium-interculturalisme.com/pdf/McGill_Inter_ en.pdf>. Acesso em: 22 jul. 2015.

CANADÁ. Immigration Act, 1976. Disponível em: <http://www.pier21.ca/research/ immigration-history/immigration-act-1976>. Acesso em: 17 jun. 2015.

. Constitution Act, 1982. Canadian Charter of Rights and Freedoms. Disponível em: <http://laws-lois.justice.gc.ca/eng/Const/page-15.html>. Acesso em: 15 nov. 2012.

. Canadian Multiculturalism Act, de 21 de julho de 1988. An Act for the preservation and enhancement of multiculturalism in Canada. Disponível em: $<$ http:// lawslois.justice.gc.ca/eng/acts/c-18.7/>. Acesso em: 15 nov. 2012.

. Employment Equity Act, 1995. Disponível em: <http://laws-lois.justice. gc.ca/eng/ acts/e-5.401/>. Acesso em: 28 jan. 2015.

CANADÁ. AADNC (Aboriginal Affairs and Northern Development Canada), 2015. Disponível em: <http://www.aadnc-aandc.gc.ca/eng/1100100010002/1100100010021>. Acesso em: 28 jan. 2015.

CANADÁ. CIC (Department of Citizenship and Immigration), 2015. Disponível em: $<$ http:// www.cic.gc.ca/english/>. Acesso em: 19 mar. 2014.

. Annual report on the operation of the Canadian Multiculturalism Act 20082009. Disponível em: <http://www.cic.gc.ca/english/pdf/pub/multi-report2011.pdf>. Acesso em: 02 nov. 2012.

. Annual report on the operation of the Canadian Multiculturalism Act 20102011. Disponível em: <http://www.cic.gc.ca/english/pdf/pub/multi-report2011.pdf>. Acesso em: 02 nov. 2012. 
. Annual report on the operation of the Canadian Multiculturalism Act 20112012. Disponível em: <http://www.cic.gc.ca/english/pdf/pub/multi-report2012.pdf>. Acesso em: 10 ago. 2015.

. Discover Canada: The Rights and Responsibilities of Citizenship, 2012. Disponível em: <http://www.cic.gc.ca/english/pdf/pub/discover.pdf>. Acesso em: 02 nov. 2012.

. Citizenship and Immigration Canada. Determine your elegibility - Citizenship, 2012. Disponível em: < http://www.cic.gc.ca/english/citizenship/become-eligibility.asp > Acesso em: 03 dez. 2012.

. Annual report on the operation of the Canadian Multiculturalism Act 20122013. Disponível em: <http://www.cic.gc.ca/english/pdf/pub/multi-ann-report_e.pdf $>$. Acesso em: 10 ago. 2015.

Annual report on the operation of the Canadian Multiculturalism Act 20132014. Disponível em: <http://www.cic.gc.ca/english/pdf/pub/multi-ar-en-2014.pdf>. Acesso em: 10 ago. 2015.

CANADÁ. EMBAIXADA CANADENSE EM BRASÍLIA. Sobre o Canadá. Informações Gerais sobre o Canadá, 2015. Disponível em <http://www.canadainternational.gc.ca/ brazilbresil/about_a-propos/overview-apercu.aspx?lang=por>. Acesso em: 15 jun. 2015.

CANADÁ. Royal Commission on Bilingualism and Biculturalism, 1969. Disponível $<$ http:// www.canadahistory.com/sections/documents/documents.html $>$. Acesso em: 18 fev. 2014. 242

CANADÁ. STATISTICS CANADA. Canada Year Book 2011. Disponível em: <http:// www.statcan.gc.ca/start-debut-eng.html>. Acesso em: 02 nov. 2012.

CONRAD, Margaret. A concise history of Canada. Cambridge: Cambridge University Press, 2012.

COURTINE, Jean-Jacques. Análise do discurso político: o discurso comunista endereçado aos cristãos. São Carlos: EdUFSCar, 2009 [1981].

DOYTCHEVA, Milena. Le Multiculturalisme. Paris: Le Decouverte, 2005.

EURONEWS [Jornal]. Angela Merkel: "multiculturalismo alemão fracassou", 17 out. 2010. Disponível em: <http://pt.euronews.net/2010/10/17/merkelmulticulturalismoalemaofracassou/>. Acesso em: 20 jul. 2011.

GAGNON, Alain-G. (org.). O dossiê constitucional Quebec-Canadá. In: GAGNON, Alain-G. (org.). Quebec: Estado e sociedade. Porto Alegre: Editora da UFRGS, 2003.

; IACOVINO, Raffaele. O interculturalismo: expandindo as fronteiras da cidadania. In: GAGNON, Alain-G. (org.). Quebec: Estado e sociedade. Porto Alegre: Editora da UFRGS, 2003.

GRIGOLETTO, Evandra. Do lugar social ao lugar discursivo: o imbricamento de diferentes posições-sujeito. In: Anais do II Seminário de Estudos em Análise do Discurso. 
Porto Alegre: UFRGS, 2004. Disponível em: <http://anaisdosead.com.br/sead2_paineis. html>. Acesso em: 15 jun. 2015.

GUIMARÃES, Eduardo. Designação e espaço de enunciação: um encontro político no cotidiano. In: Letras, n. 26, UFSM, 2003. Disponível em: <http://cascavel.ufsm.br/ revistas/ojs-2.2.2/index.php/letras/article/view/11880>. Acesso em: 15 set. 2015.

HEYWOOD, Andrew. Ideologias políticas (v.2): do feminismo ao multiculturalismo. São Paulo: Ática, 2010.

HORTA NUNES, José. A invenção do dicionário brasileiro: transferência tecnológica, discurso literário e sociedade. In: Revista argentina de historiografía lingüística, v. 5, n. 2, 2013. Disponível em: <http://www.rahl.com.ar/index.php/rahl/article/view/71/107> Acesso em: 20 out. 2015.

KARMIS, Dimitrios. Pluralismo e identidade(s) nacional(ais) no Quebec contemporâneo: esclarecimentos conceituais, tipologia e análise do discurso. In: GAGNON, Alain-G. (org.). Quebec: Estado e sociedade. Porto Alegre: Editora da UFRGS, 2003.

KYMLICKA, Will. Théories récentes sur la citoyenneté. Rapport présenté pour Politiques ministérielles et recherche. In: Multiculturalisme et Citoyenneté, Canada, Ottawa, 1992.

. Federalismo, nacionalismo y multiculturalismo. In: RIFP, v. 7, p. 20-54, 1996. Disponível em: <https://www.zotero.org/spartakku/items/itemKey/3R96BQMH>. Acesso em: 15 ago. 2012.

. Multiculturalismo: o sucesso, o fracasso e o futuro. In: Interfaces Brasil/ Canadá, v. 14, n. 18, 2014. Disponível em: <http://www.revistas.unilasalle.edu.br/index. php/interfaces/ article/view/1576>. Acesso em 15 set. 2015.

LACZKO, Leslie. Pluralism and inequality in Quebec. Toronto: University of Toronto Press, 1995.

LAROUSSE. Le Grand Larousse. Paris, 2015.

LONGMAN. Longman Dictionary of Contemporany English. Essex: Pearson Education Limited, 1987.

MAHROUSE, G. Reasonable accommodation in Quebec: the limits of participation and dialogue. In: Race and Class, 52 (1), 2010. Disponível em: <http://rac.sagepub.com/ content/52/1/85.short>. Acesso em: 10 ago. 2015.

MARIANI, Bethania. O PCB e a imprensa. Campinas: Unicamp, 1998.

. Colonização Linguística. Campinas: Pontes Editores, 2004.

MCNAUGHT, Kenneth. The Penguin History of Canada. Toronto: Penguin Books, 1988 [1969].

MORTON, Desmond. Breve história do Canadá. São Paulo: Editora Alfa-Ômega, 1989 [1983]. 
NASSRALLAH, Mireille. Challenges in Canadian cultural discourses: multiculturalism visà-vis interculturalism and the political othering of Canada's cultural fabric, 2014. Dissertação (Master of Arts in Communication) - Faculty of Arts, University of Ottawa, Ottawa, 2014.

ORLANDI, Eni Pulcinelli. Silêncio e implícito (Produzindo a monofonia). In: GUIMARÃES, Eduardo (org.). História e sentido na linguagem. Campinas: Pontes, 1989.

(Org). Discurso Fundador: A formação do país e a construção da identidade nacional. Campinas: Pontes, 2003 [1993].

(Org). Política linguística no Brasil. Campinas: Pontes, 2007.

[1999].

. Análise de discurso: princípios e procedimentos. Campinas: Pontes, 2007

. Espaços linguísticos e seus desafios: convergências e divergências. In: Rua, n. 18, v. 2, 2012b. Disponível em: <http://www.labeurb.unicamp.br/rua/pages/home/ capaArtigo.rua? id=131>. Acesso em: 28 abr. 2013.

OXFORD. The Oxford English Dictionary. Oxford: Oxford University Press, 1989.

PÊCHEUX, Michel. Semântica e Discurso. Campinas: Unicamp, 2009 [1975].

Análise automática do discurso (AAD-69). In: GADET, Françoise; HAK, Tony (orgs.). Por uma análise automática do discurso. Campinas: Unicamp, 2010 [1990]. . AAnálise de Discurso: três épocas (1983). In: GADET, Françoise; HAK, Tony (orgs.). Por uma análise automática do discurso. Campinas: Unicamp, 2010 [1990].

PÚBLICO [Jornal]. David Cameron denuncia fracasso do multiculturalismo, 05 fev. 2011. Disponível em: http://www.publico.pt/Mundo/david-cameron-denuncia-fracassodomulticulturalismo_1478771. Acesso em: 20 jul. 2011.

QUEBEC. Conhecer, respeitar, partilhar: valores em comum da sociedade quebequense, 2009. Disponível em: <https://www.immigration-quebec.gouv.qc.ca/publications/pt/ DepliantValeurs-Communes-PT.pdf>. Acesso em: 10 ago. 2015.

RATTANSI, Ali. Multiculturalism: a very short introduction. Oxford: Oxford University Press, 2011.

RICHTER, Miriam Verena. Creating the National Mosaic: Multiculturalism in Canadian Children's Literature from 1950 to 1994. New York: Rodopi, 2011.

ROBERT. Dictionnaire Le Grand Robert. Montreal: Dicorobert, 1989.

RONCARATI, Claudia; BARBOSA DA SILVA, Diego; PONSO, Letícia Cão. Um olhar crítico sobre a sociometria da língua portuguesa. In: Gragoatá, n. 32, jan./jun. 2012, p. 75 98. Disponível em: <http://www.gragoata.uff.br/index.php/gragoata/article/view/118>. Acesso em: 20 mar. 2014.

SAFATLE, Vladimir, Multiculturalismo. In: WILLIAMS, Raymond. Palavras-chave: um vocabulário de cultura e sociedade. São Paulo: Boitempo, 2007. 
SALÉE. Daniel. O Estado quebequense e a questão autóctone. In: GAGNON, Alain-G. (org.). Quebec: Estado e sociedade. Porto Alegre: Editora da UFRGS, 2003.

SAPO [Jornal]. Sarkozy junta-se ao coro anti-multiculturalismo, 11 fev. 2011. Disponível em: <http://sol.sapo.pt/inicio/Internacional/Interior.aspx?content_id=11511>. Acesso em: 20 jul. 2011.

TAYLOR, Charles (org.). Interculturalism or multiculturalism? In: Philosophy \& Social Criticism, v. 38, may/jun. 2012, p. 413-423. Disponível em: <http://www.resetdoc.org/ story/00000022267>. Acesso em: 19 jun. 2015.

TRUDEAU, Pierre Elliott. Announcement of Implementation of Policy of Multiculturalism within Bilingual Framework. Ottawa: Ottawa: House of Commons, 1971. Disponível em: $\quad<$ http://www.canadahistory.com/sections/documents/Primeministers/trudeau/ docsonmulticulturalism.htm>. Acesso em 02 nov. 2012.

TURNER, B. S. Citizenship and the crisis of multiculturalism. In: Citizenship Studies, 10(5), 2006. Disponível em: <http:/www.tandfonline.com/doi/ abs/10.1080/13621020600955041? journalCode=ccst20\#.VdnIGvlViko $>$. Acesso em: 10 ago. 2015 .

\section{Notas}

${ }^{1}$ Doutorado em Estudos de Linguagem (UFF), pesquisador do Arquivo Nacional do Brasil, Rio de Janeiro, RJ vsjd@uol.com.br.

2 Outros autores como Safatle (2007, p. 448) e Nassrallah (2014, p. 26) falam que o termo multiculturalismo foi criado na Suíça nos anos 1940 ou 1950.

${ }^{3}$ No Canadá há ainda uma lei específica para isso: o Canadian Multiculturalism Act, de 1988, bem como já houve um ministério responsável por essas políticas, o Department of Multiculturalism and Citizenship, criado, em 1991, mas extinto em 1996 para formar o Department of Canadian Heritage. Em 16 de agosto de 2013, quando a política multicultural foi assumida por Jason Kenney, o órgão passou a se chamar Department of Citizenship, Immigration and Multiculturalism. Com a posse de Justin Trudeau, neto de Pierre Trudeau, como primeiro-ministro canadense, em novembro de 2015, o ministério mudou novamente de nome, passando a se chamar Department of Immigration, Refugees, and Citizenship (CANADÁ. CIC, 2015).

${ }^{4}$ Sob o olhar do estatístico, comparando com o Brasil, seria como se 40 milhões de brasileiros tivessem nascido no exterior e o país recebesse anualmente 1,5 milhão de imigrantes por ano, o equivalente respectivamente à população dos estados de São Paulo e do Tocantins.

${ }^{5}$ Kymlicka (2014 [2012], p. 130 e 131) e Aguirre (2014, p. 199) chamam de disneyficação, essa propaganda para vender a diversidade para o exterior.

${ }^{6}$ Ainda que o governo tenha reconhecido o tratamento diferenciado e discriminatório dado ao longo da história a muitas minorias culturais, como, por exemplo, por meio do pedido formal de desculpas do governo aos povos indígenas, em 2008, essas discriminações acabam sendo apagadas pelo funcionamento do mito do Canadá como um país aberto e tolerante às variadas culturas.

7 Entre os muitos movimentos reivindicatórios de francofalantes no Canadá destacamos: as rebeliões de 18371838 contra a Coroa Britânica e a de 1917, contrária ao alistamento obrigatório durante a I Guerra Mundial (1914-1918); o sequestro de Pierre Laporte, ministro do trabalho do Quebec, pela Front de Libération du Québec (FLQ), em 1970; a crise em torno da aprovação da emenda constitucional de 1982 e os plebiscitos realizados em 1980 e em 1995, quando $60 \%$ e 50,6\% da população votaram contrariamente à independência (CONRAD, 2012).

${ }^{8}$ Entre os fatos que marcaram a Révolution Tranquille no Quebec, liderada por Jean Lesage, e sob inspiração da independência das colônias francesas na África, estão: a criação do Ministère des Affaires culturelles e do Office de la langue française (1961); a nacionalização das empresas produtores de energia elétrica (1963); a 
criação do Ministère de l'Éducation do Quebec (1964); o estabelecimento, condenado pelo Canadá, de relações diplomáticas com a França, (1966); a visita do presidente Charles De Gaulle com pronunciamento a favor da independência do Quebec (1967); a fundação do Parti québécois, de caráter independentista (1968) e a fuga de anglofalantes de Montreal para Toronto (MORTON, 1989 [1983]; CONRAD, 2012).

${ }^{9} \mathrm{~A}$ Bi and Bi Commission, como também é chamada, foi criada com a intenção de reconhecer a igualdade de direitos de canadenses francofalantes frente aos anglofalantes, mas o próprio nome da comissão mostra que, embora se tente produzir outras redes de significância, a marca da colonização permanece, na ilusão da obviedade de que Royal se refira ao Canadá e não ao Reino Unido. Taylor (2012) atribui ao que ele chama de "anglo-normatividade" o direcionamento britânico sobre a construção da identidade canadense marcado pela relação de apoio ao Império Britânico e à Commonwealth durante as duas guerras mundiais, pela excitação com os acontecimentos da monarquia britânica ou mesmo na referência à realeza britânica na denominação das forças armadas do país como Royal Canadian Navy/Marine Royale Canadienne e Royal Canadian Air Forces/Aviation royale du Canada ou da Royal Canadian Mounted Police (RCMP)/Gendarmerie royale du Canada. A memória britânica também esteve marcada na bandeira canadense até 1965, quando adotouse uma nova bandeira, abolindo a Union Jack britânica no canto superior esquerdo sob o fundo vermelho (CONRAD, 2012, p. 240).

${ }^{10}$ Tradução nossa: “a) Que distritos bilíngues sejam criados em regiões do Canadá, onde os membros da comunidade minoritária, francesa ou inglesa, compõem 10\% ou mais da população local; b) Que os pais possam ter seus filhos frequentando escolas na língua de sua escolha em regiões onde há demanda suficiente; c) Que Ottawa se torne uma cidade bilíngue e d) Que o inglês e o francês sejam declaradas línguas oficiais do Canadá". ${ }^{11}$ Paul Yuzyk é apontado nos relatórios anuais produzidos pelo governo canadense sobre a situação das políticas multiculturalistas no país como o pai do multiculturalismo, tendo inclusive batizado um prêmio, em 2009, com o seu nome, o Paul Yuzyk Award for Multiculturalism como forma de reconhecimento a indivíduos e grupos que promovem o multiculturalismo no Canadá (CANADA. CIC).

${ }_{12}$ De acordo com Heywood (2010, p. 95), o termo multiculturalismo surgiu pela primeira vez no Canadá em 1965 "para descrever uma forma específica de se lidar com a questão da diversidade cultural". Já segundo Doytcheva (2005, p. 7), "o adjetivo [multicultural] foi identificado pela primeira vez na língua inglesa em 1941 para designar uma sociedade cosmopolita" enquanto que "o substantivo [multiculturalismo] apareceu no começo dos anos 1970 na Austrália e no Canadá para qualificar as políticas públicas cujo objetivo é promover e valorizar a diversidade cultural das sociedades australiana e canadense, bem como reavaliar a identificação e a adesão das populações minoritárias", somente sendo registrado no Oxford English Dictionary em 1989 (tradução nossa).

${ }^{13}$ Ser identificado a uma cultura não é algo óbvio, da mesma forma como ser identificado como falante de uma língua. O português utilizado na imprensa oficial é o mesmo de uma conversa informal em um bar? O português angolano é igual ao português europeu? O português brasileiro é a mesma língua que o galego? A língua falada no Nordeste brasileiro é o mesma daquela falada no Sul do país?

${ }^{14}$ É a inscrição do discurso do multiculturalismo no discurso sociológico que faz com que se construa a ilusão de que essas políticas podem ser mensuradas e serem feitos rankings de países mais e menos multiculturais como faz Kymlicka (2014 [2012], p. 133 e 159) a partir de evidências como a existência de leis a favor de imigrantes e de currículos escolares que abarquem o tema ou o acesso dos imigrantes ao mercado de trabalho. Sobre a construção de rankings, bem como a ilusão que eles constroem, conferir Roncarati et alii (2012).

${ }^{15}$ Vale lembrar que foi justamente a temática da imigração que deu início à Sociologia Urbana, criada pela Escola de Chicago, no início dos anos 1920, cujos expoentes são: William Thomas, Florian Znaniecki, Robert Park e Louis Wirth.

${ }_{16}$ Primeiramente, como vimos, a Royal Commission defendeu que, oficialmente, o Canadá se tornasse um país bilíngue, posteriormente, foi favorável a que o país adotasse o multiculturalismo como política oficial (RATTANSI, 2011, p. 8).

${ }^{17}$ Tradução nossa com itálicos nossos: "A distinção entre língua e cultura nunca foi claramente definida. O próprio nome da comissão real cujas recomendações que agora procuramos implementar tendem a indicar que o bilinguismo e biculturalismo são indivisíveis. Mas, biculturalismo não descreve adequadamente nossa sociedade; o multiculturalismo é mais preciso. O Official Language Act designa dois idiomas, o inglês e o francês, como as línguas oficiais do Canadá, para efeitos em todas as instituições do Parlamento e do governo; nenhuma referência foi feita às culturas, e essa lei também não prejudica o papel de todas as línguas, como instrumentos das diversas culturas canadenses".

${ }^{18}$ Kymlicka (2014 [2012], p. 156), da posição do sociólogo, inclusive, reconhece a importância da manutenção do bilinguismo para que se mantenha esse controle do Estado sobre a língua, pois, segundo ele, mesmo que os 
imigrantes façam uma "aliança para lutar por melhor tratamento e acomodações, tal aliança só pode ser desenvolvida utilizando a língua e dentro das instituições do país que os recebeu".

19 Cabe aqui dizer que não estamos questionando a (im)possibilidade de construir um Estado multilíngue ou com muitas línguas oficiais, mas o efeito produzido pelo discurso do multiculturalismo.

${ }^{20} \mathrm{O}$ processo de reforma, que foi uma resposta ao plebiscito de 1980 sobre a independência do Quebec, ficou conhecido como patriation, pois a partir dessa data, o Canadá deixou de ser governado por leis britânicas. Nesse processo de reforma constitucional foi incorporada à Constituição a Canadian Charter of Rights and Freedoms/ La Charte canadienne des droits et libertés, que introduzia na legislação canadense princípios da Declaração Universal dos Direitos Humanos (GAGNON, 2003).

${ }^{21}$ Para Balthazar (1995, p. 47) a emergência do multiculturalismo ocorreu sob outras condições de produção que não a das reivindicações de outros grupos culturais no Canadá, porque o primeiro ministro Trudeau buscava reduzir a cultura do Quebec a apenas mais um dos muitos componentes étnicos do Canadá, implicando o reconhecimento de todas as culturas étnicas como membros iguais do Canadá, negando a natureza dualista do país. Turner (2006, p. 611) na mesma linha argumenta que a formação do multiculturalismo foi a tentativa de Trudeau para combater a agenda de autonomia e independência do Parti Québécois.

${ }^{22}$ Um pouco antes do deslocamento de multiculturalismo para interculturalismo, nos anos 1960, no Quebec, após a Révolution Tranquille, é possível observar outros deslocamentos sobre como os francofalantes se autodenominavam, de Canadiens passaram a se chamar Canadiens français, depois Franco-Québécois e por fim Québécois (KYMLICKA, 1992, p. 45).

${ }^{23}$ Tradução nossa: "entre, entre, no meio, entre os dois, no meio".

${ }^{24}$ Tradução nossa: "exprime espaçamento, distribuição (no espaço e no tempo), ou relação, uma ligação recíproca”.

${ }_{25}$ Para Karmis (2003, p. 112-113) torna-se difícil, inclusive, pensar numa proposta de diálogo feita por Quebec, por meio do interculturalismo, quando o pertencimento do Canadá é sequer mencionado nos documentos que promovem a integração no estado.

26 Tradução nossa: "o biculturalismo não descreve adequadamente a nossa sociedade; o multiculturalismo é mais preciso".

27 Tradução nossa da entrada -ism do Oxford (1989): "Formando um simples substantivo de ação, nomeando o processo, ou a ação concluída, ou o seu resultado (raramente concreto) (...); 2. Formar o nome do sistema de teoria ou prática religiosa, eclesiástica, filosófica, política, social, etc., às vezes, fundada sob o nome de seu sujeito ou objeto, às vezes sob o nome de seu fundador (...) b. Mais da natureza da classe dos nomes ou termos descritivos, por doutrinas ou princípios, como agnosticismo (...) o feminismo (...); 3. Formação de um termo que denota a peculiaridade da característica, esp. de linguagem".

28 Tradução nossa da entrada -ism do Longman (1987): "Sufixo [em substantivos] 1 uma crença política ou religiosa baseada em um princípio particular ou nos ensinamentos de uma pessoa em particular: o socialismo / budismo 2 a ação ou processo de fazer algo (...) 3 uma ação ou observação que tem uma qualidade particular (...) 4 o estado de ser como algo ou alguém, ou de ter uma qualidade particular (...) 5 doença causada pelo excesso de algo: o alcoolismo 6 a prática de tratar as pessoas injustamente por causa de algo: sexismo (...) racismo (...)". 29 Tradução nossa da entrada -ity do Longman (1987): "Sufixo [em substantivos] o estado de ter uma qualidade particular, ou algo que tem essa qualidade: com grande regularidade (= regularmente)".

30 Tradução nossa da entrada -isme do Robert (1989): "Sufixo, do grego -ismos (que tinha uma extensão paralela ao sufixo verbal -idzein $\rightarrow$-iser, e que reconhece o elemento nasal -mo- para a origem de -me Dan entusiasmo, marasmo, miasmo, espasmo...), aprovada pelo em francês com o tempo baixo -ismus Latina, e que é utilizado para a formação de substantivos derivados do sexo masculino que denotam uma profissão, um parecer (ex:. socialismo, jornalismo) os membros do grupo ou um sistema (ex:. estruturalismo), etc. $=>$-iste. O sufixo -ismo é muito produtivo; adicionado a um substantivo ou adjetivo formas termos políticos e sociais, com o valor axiológico "sistema de opiniões" ou "atitude, tendência"; termos filosóficos, religiosos ou científicos ( "doutrina" ou "crenças"); termos literários e artísticos ( "escolas, tendências"). Ele sempre tem o valor de "atitude positiva com relação a (a crença, etc., representada pela base)" - Um segundo valor é o do sufixo "atitude e atividade "consistente com a tendência expressa ou modelo a base (bovarysm, construtivismo, etc.) ou a favor de uma pessoa, um grupo humano, etc. (Americanismo; $\rightarrow$ Pro). - Na Costa tem valor de "actividade profissional" (Jornalismo) tem ismo o de "caráter ou estado particular, a doença" (mongolismo virilismo) ou "qualquer atividade" (canoagem, etc.). Além das bases nominais e adjetivas do léxico, -ismo é construído com nomes próprios, especialmente na política ( $=>$ Gaullismo; $\rightarrow$ Pompidolisme; Giscardism; barrisme; mitterrandisme ...), verbos (dirigismo), frases (aquoibonisme).".

31 Tradução nossa da entrada -(i)té do Robert (1989): "Sufixo (do lat. -itas) para formar substantivos a partir de adjetivo ou excepcionalmente de nome. Adj. terminados em -able e -ible = -abilité, -ibilité (ex: manobrabili- 
dade, a reversibilidade); adj. em =-aire $=$-arité (ex: primariedade); adj. em -al e -el $=$-alité (ex: atonalidade, funcionalidade, fiscalité); adj. em -eux = -osité (ex:. adiposidade, schistosité); adj. em -se =-ivité (ex:. esportividade, positividade); adj. em -ique (ex:. historicidade). Outros adj. (ex:. factice = artificialidade). Nomes (ex:. alumine = aluminité).".

${ }^{32}$ Tal apagamento é tão forte que na busca a diversos dicionários monolíngues de inglês e francês, como o Oxford, Webster, Robert e Larousse, não encontramos entrada para multiculturality/multiculturalité, somente para multculturalism/multiculturalisme, multicultural/multiculturel, multiculturalist e multiculturally embora pesquisando no google encontremos 70 mil ocorrências para multiculturality e 110 mil para multiculturalité.

${ }^{50} \mathrm{O}$ Oxford (1989) tem inclusive uma entrada para o termo ism, enquanto substantivo que significa: "a form of douctrine, theory, or practice having, or claiming to have, a distinctive character or religion: chiefly used disparagingly". Tradução nossa: "uma forma de doutrine, teoria, ou prática que se tem ou que se alega ter, um caráter distintivo ou religião: principalmente usado depreciativamente".

${ }^{33}$ Após a II Guerra Mundial, o Holocausto e o surgimento dos direitos humanos de terceira geração, relacionados à solidariedade (BOBBIO, 2004), esses dizeres foram/são interditados pelo discurso (formação discursiva) dos direitos humanos.

${ }^{34}$ Esse enunciado foi proferido por diversos governantes de países europeus como Nicholas Sarkozy (França), Angela Merkel (Alemanha) e David Cameron (Reino Unido), em 2010 e 2011 e não é à toa que retoma um outro, no início dos anos 1990, bastante utilizado na época para se referir ao fim da União Soviética: "o comunismo fracassou". Como provocação, perguntamo-nos o que teria fracassado? As ações do Estado a favor da diversidade ou a interpelação dos imigrantes como sujeitos ocidentais?

${ }^{35}$ Já se observarmos o verbete multiculturalism no dicionário Longman (1987) temos: "the belief that it is important and good to include people or ideas from many different countries, races, or religious". Tradução nossa: "a crença de que é importante e bom incluir pessoas ou ideias de muitos países diferentes, raças ou religião". É esse efeito de sentido, enquanto crença em algo bom, que para nós o sufixo-ism/-isme produziu.

${ }^{36}$ Tomamos sequência discursiva como Courtine (2009 [1981]), como unidade igual ou superior à frase, recortada do texto de acordo com o objetivo do analista (ORLANDI, 2007 [1999]).

${ }^{37}$ Esses relatórios anuais foram instituídos pelo Canadian Multiculturalism Act e são feitos desde 1988.

${ }^{38}$ Tradução nossa: "SD1.1: Para entender o que significa ser canadense, é importante saber sobre nossos três povos fundadores - aborígene, francês e britânico". Como sabemos, na língua inglesa não há plural para adjetivos. Assim, a princípio poderíamos traduzir para povos aborígenes, franceses e britânicos. Entretanto, como se observa nas duas sequências posteriores (SD1.2 e SD1.3) nomeiam-se três pilares principais e três nações fundadoras, desfazendo a possibilidade de plural, embora em outros momentos nos relatórios anuais compareça a designação Aboriginal Peoples, ou seja povos aborígenes, no plural.

${ }^{39}$ Tradução nossa: "SD1.2: O Canadá, desde o início, tem sido uma sociedade diversificada com uma história de acomodar os recém-chegados e os seus cidadãos. A diversidade no Canadá foi construída sobre três pilares principais: os povos aborígine, francês e britânico. Com o tempo, essa diversidade tem sido complementada por milhões de recém-chegados ao Canadá com várias origens étnicas e religiosas.".

${ }^{40}$ Tradução nossa: "SD1.3: A sociedade canadense repousa sobre uma base sólida, construída pelas três nações fundadoras, os povos aborigene, francês e britânico, com instituições fortes e uma vibrante cultura e identidade nacionais e valores compartilhados.".

${ }^{41}$ Tradução nossa: "SD1.4: A chegada de comerciantes europeus, missionários, soldados e colonos mudou a maneira natural de vida para sempre. Um grande número de aborígines morreram de doenças europeias para as quais eles não tinham imunidade. No entanto, aborigenes e europeus formaram fortes laços econômicos, religiosos e militares nos primeiros 200 anos de convivência, que são as bases do Canadá".

${ }^{42}$ No Brasil também encontramos essa memória de fundação do país no encontro, só que no lugar de três povos, de três raças: índia, portuguesa e negra.

${ }^{43}$ Isso ocorre sobretudo, a partir do Multiculturalism Act, editado em 1988.

${ }^{44}$ Colocamos maus entre parênteses, pois, se observarmos os primeiros relatos de viajantes europeus ao redor do mundo, entre eles no continente americano, veremos que uma das designações mais utilizadas para se referir aos povos autóctones era selvagem, com um sentido bastante depreciativo. Com a chegada dos jesuítas no continente americano, inaugura-se uma outra discursividade sobre esses povos, que passam a ser designados como bons selvagens. A partir deste momento, a discursividade anterior passa a designá-los como maus selvagens.

${ }^{45}$ Essa discursividade não permite, inclusive, enunciados do discurso científico de que o homem teria migrado da Ásia para a América pelo Estreito de Bering, há milhares de anos.

46 Esta designação First Nations/Premières Nations passou a ser utilizada, a partir de 1982, pelos indígenas canadenses em substituição à designação indian, considerada depreciativa. Nesse mesmo ano, os povos indí- 
genas modificaram o nome da National Indian Brotherhood, organização criada para representá-los, para Assembly of First Nations/Assemblée des Premières Nations. Essa designação produz o efeito de sentido oposto aos enunciados de que os europeus seriam os fundadores do país, mesmo ao lado dos autóctones. Quando se diz First Nations/Premières Nations, afirma-se que os povos indígenas são as primeiras nações do Canadá e não franceses e britânicos. No entanto, tal enunciação se dá por meio da língua europeia e pelo significante nation, dentro do processo de colonização linguística. Dizer outra história que não a do colonizador só é possível pela sua língua, mesmo que seja ressignificado, afinal como já mostrou Mariani (2004, p. 24): o discurso do colonizador "se impõe pela força e pela escrita, ou melhor, impõe-se com a força institucionalizadora de uma língua escrita gramatizada que já traz consigo uma memória, a memória do colonizador sobre a sua própria história e sobre a sua própria língua".

${ }^{47}$ Analisando a historiografia canadense sob a posição da invasão, encontramos muitas revoltas de indígenas contra a dominação colonialista europeia, como a Guerra Franco-Indígena, de 1754 a 1763, que opôs povos indígenas como aliados tanto de britânicos como de franceses na disputa por terras, além de o país ser influenciado durante todo o conflito de 1778 a 1890, quando os Estados Unidos massacraram os povos indígenas, rumo à conquista do oeste do seu atual território. Mas nas SDs analisadas elas não comparecem, tampouco nos documentos canadenses analisados. Sobre as formas de resistências atuais dos indígenas no Canadá, cf. Salée (2003). ${ }^{48}$ Sobre o lugar social, Grigoletto (2004, p. 4) afirma: "partindo do conceito de formações imaginárias, cunhado por Pêcheux (2010 [1969]), podemos dizer que as imagens que os interlocutores de um discurso atribuem a si e ao outro são determinadas por lugares empíricos/institucionais, construídos no interior de uma formação social". O que estamos tentando dizer é que a emergência do discurso do multiculturalismo colocou os povos autóctones do Canadá em um outro lugar social, de povo fundador, bem distinto daquele de povo colonizado, da discursividade dominante anteriormente. 